\title{
Las drogas de uso recreativo en el derecho penal español
}

\author{
Sergio Herrero Álvarez \\ Abogado \\ Enviar correspondencia: Pintor Mariano Moré 22 - $3^{\circ}$ A. 33206 Gijón (Asturias) \\ Tfno: 985348 328. E-mail: sh@herreroabogados.com
}

\section{Resumen}

Se examina la regulación de las drogas en el Código Penal español y las sentencias sobre esta materia del Tribunal Supremo. La legislación penal española no contiene una regulación precisa de algunas cuestiones relativas a las drogas. Por ello, la jurisprudencia reviste gran importancia, al haberse encargado de rellenar esos vacíos legales. España considera como drogas ilícitas las sustancias catalogadas en los tratados internacionales existentes, entre las que se incluyen la práctica totalidad de drogas de uso recreativo. El consumo de drogas ilegales es sancionable administrativamente con multas, pero no constituye delito. Tampoco es delito la tenencia de drogas para el consumo propio. El tráfico de drogas es delito penado con prisión, cuya duración depende, en parte, de la nocividad de la sustancia y, en parte, de la gravedad de la conducta delictiva. El Código Penal distingue entre drogas "duras" y "blandas", en función del peligro de la sustancia para la salud de sus consumidores. Las drogas de uso recreativos más importantes son calificadas como drogas "duras", y su tráfico se sanciona con pena mínima de tres años de prisión y pena máxima que en casos excepcionales puede alcanzar veinte años y tres meses de prisión.

Palabras claves: Código Penal español, trafico de drogas, cocaína, anfetaminas, drogas recreativas

\section{Summary}

A review of the regulations on drug use and trafficking in the Spanish Penal Code is made. Sentences given by the Supreme Court are also examined. The Spanish laws have not a specific regulation on some questions related with drugs. Due to this, jurisprudence is extraordinarily useful to resolve open legal questions in this field. In Spain, illicit drugs are considered those which are so catalogued in international treaties, as most off "recreational drugs". Drug consumption is not considered as an offence, but it is punished with a fine. In the same way, it is permitted drug possession for self-use. Drug trafficking is punished with imprisonment, which duration depends on the risk for the health of the substance and on the severity of criminal behaviour. The Spanish Penal Code distinguishes between "soft" and "hard" drugs, based on the risk for health. Most important recreational drugs are considered as "hard", and its trafficking is punished with imprisonment with a minimum of three years and a maximum of twenty years and three months in some extreme cases.

Key Words: Spanish Penal Code, drug trafficking, cocaine, amphetamines, club drugs

\section{INTRODUCCIÓN}

$\mathbf{E}$ I objeto del presente estudio es el tratamiento de las "drogas de uso recreativo" en el derecho penal español, entendiendo por tales sustancias, a este fin, cocaína, MDMA, MDA, MDEA, anfetaminas, LSD,
GHB, ketamina y otros alucinógenos y psicoestimulantes similares. Analizaremos su regulación en el Código Penal y el conjunto de sentencias del Tribunal Supremo referidas a ellas dictadas hasta el momento (enero de 2003). 
Como es obvio, cualquier ordenamiento jurídico ha de partir, al establecer su regulación sobre "drogas", de la definición y delimitación precisas de las sustancias que considere como tales. Una vez perfilado ese concepto de "droga", el Estado ha de decidir la legalidad o ilegalidad de la distribución de esas sustancias. De optarse por la ilegalidad, el tráfico o suministro de esos productos puede ser sancionado administrativamente o mediante la aplicación de penas. En cualquiera de los casos, puede establecerse una sanción o pena única para cualquier conducta de tráfico ilegal de drogas o castigarse más gravemente ciertas actuaciones. A su vez, esa diferente gravedad de algunas acciones puede relacionarse con el tipo de drogas objeto del tráfico, si se consideran algunas de ellas como más nocivas que otras, en cuyo caso habrá que distinguir legalmente dos o más categorías de drogas.

La solución de las cuestiones expuestas en el derecho español, especialmente en lo referido a las drogas recreativas, constituye el objeto del presente capítulo, en el cual analizaremos el tratamiento de las sustancias que se consideran como drogas, las sanciones penales correspondientes y los criterios de graduación de la gravedad de las mismas, así como los principales problemas interpretativos y probatorios surgidos en la praxis de los tribunales.

Como veremos, España, en cumplimiento de los tratados internacionales que ha suscrito, castiga penalmente el tráfico ilícito de drogas e incluye entre ellas a la casi totalidad de las sustancias recreativas inicialmente mencionadas.

La regulación concreta de los delitos relativos al tráfico ilícito de drogas se encuentra, en la legislación española, en los artículos 368 y siguientes del Código Penal de 1995, en vigencia desde el día 25 de mayo de 1996.

El artículo 368 del Código, eje de toda la regulación examinada, sanciona a quienes "ejecuten actos de cultivo, elaboración o tráfico, o de otro modo promuevan, favorezcan o faciliten el consumo ilegal de drogas tóxicas, estupefacientes o sustancias psicotrópicas, o las posean con aquellos fines". La pena correspondiente a los responsables de esos delitos oscilará entre tres y nueve años de prisión, cuando la droga objeto de tráfico sea una sustancia o producto "que causen grave daño a la salud", y se mantendrá entre uno y tres años de prisión en los demás casos, es decir, cuando la droga de que se trate no sea gravemente dañina. Además, en todos los supuestos, la pena privativa de libertad irá acompañada de otra pena de multa, cuya cuantía dependerá del valor de la droga, suponiendo entre el tanto y el triplo de dicho valor, si se trata de sustancias gravemente dañinas, y entre el tanto y el duplo cuando se trafique con otras sustancias.

Por otra parte, el artículo 369 del Código Penal tipifica nueve supuestos distintos en los que las penas de prisión que han de imponerse serán las superiores en un grado a las establecidas en el artículo 368. Finalmente, el artículo 370 crea unos tipos delictivos superagravados, en los que las penas de prisión a imponer son las superiores en dos grados a las penas básicas del primer artículo citado. A todo ello ha de añadirse la existencia, junto con las penas de prisión indicadas y las multas correspondientes en cada caso, de diversas penas de inhabilitación detalladas en el artículo 372.

Del conjunto de preceptos mencionados, y de los demás relativos al tráfico ilícito de drogas, nacen las cuestiones que a continuación tratamos. Dada la indefinición de los textos legales sobre bastantes puntos relevantes, se hace obligado el examen detallado de la jurisprudencia al respecto, para conocer cómo han sido interpretados y "rellenados" esos vacíos legales. Por ello, la cita abundante de sentencias del Tribunal Supremo español será imprescindible.

\section{2. ¿QUÉ SUSTANCIAS SON DROGAS ILE- GALES?}

El texto del artículo 368 del Código Penal no ofrece un concepto genérico de droga, ni 
define las características que haya de poseer una sustancia para ser considerada, a efectos jurídico-penales, como tal. Tampoco lo hacía el anterior Código de 1973, que estuvo vigente hasta el año 1996. El actual artículo 368, al igual que el artículo 344 del Código derogado, se refieren a las conductas delictivas relacionadas con "drogas tóxicas, estupefacientes o sustancias psicotrópicas", pero sin determinar qué se entiende por las mismas ni contener una enumeración de dichas sustancias.

Esa indefinición legal del objeto material del delito ha sido objeto de críticas fundadas por la doctrina penal, proponiendo los diversos autores, ante las consiguientes dificultades interpretativas, un conjunto de soluciones que pueden resumirse en dos posturas fundamentales.

Por una parte, la línea mayoritaria entiende que el artículo 368, constituye lo que se denomina técnicamente una "ley penal en blanco", es decir, un precepto penal, con el exigible rango legal, que describe una figura delictiva y determina sus condiciones de sancionabilidad, los rasgos básicos de la conducta castigable y la pena a imponer, pero que no define completamente algún extremo del "supuesto de hecho" delictivo sino por referencia a otras normas extrapenales (generalmente de naturaleza administrativa), con cuyo contenido ha de "integrarse" el tipo o figura penal. Al respecto viene proclamando el Tribunal Supremo la admisibilidad constitucional de ese tipo de normas (sentencia de 25 de noviembre de 1996) afirmando que "son leyes penales en blanco aquellas cuyo supuesto de hecho debe ser completado por otra norma producida por una fuente jurídica legítima" (sentencia de 20 de setiembre de 1990).

Según esta doctrina mayoritaria, el artículo 368 del Código, considerado como ley penal en blanco, deberá ser completado con los listados de sustancias contenidos en los Convenios internacionales de los que España es parte. Será, por lo tanto, la inclusión o no de una sustancia determinada en esos listados internacionales, periódicamente actualizados, lo que determine su consideración legal como droga a efectos penales en nuestro ordenamiento jurídico, y la consecuente persecución de su posible tráfico. Esta postura doctrinal ha venido contando, en general, con el refrendo jurisprudencial del Tribunal Supremo español, expresado, entre muchas otras, en sus sentencias (STS, en adelante) de 11 de octubre de 1974, 22 de junio de 1981, 25 de octubre de 1982, 4 de febrero de 1984, 7 de mayo de 1984, 15 de noviembre de 1984, 19 de enero de 1985, 15 de julio de 1985, 4 de marzo de 1988, 12 de julio de 1990, 24 de diciembre de 1992, 28 de abril de 1994, 25 de mayo 1994, 27 de setiembre de 1995, 5 de febrero de 1996, 18 de marzo de 1996 y 11 de setiembre de 1996).

Cabe decir que con esta remisión a un "elenco rígido" de sustancias, previamente establecido, parece satisfacerse, mejor que con la segunda postura que a continuación analizaremos, el principio de legalidad penal recogido en el artículo $25-1^{\circ}$ de la Constitución Española.

El otro sector doctrinal aludido entiende, por el contrario, que la falta de determinación de las sustancias "prohibidas" permite la creación de un concepto de droga propio de nuestro ordenamiento jurídico, buscado a partir de una adecuada interpretación sistemática y teleológica de los preceptos en juego, y configurado con independencia o, al menos, cierta autonomía, de los listados contenidos en los tratados internacionales sobre la materia. Según esta teoría, denominada de la definición elástica, del Código Penal no se desprende que haya de acudirse a los Convenios internacionales o a la legislación administrativa complementaria para entender el sentido y alcance de las expresiones contenidas en el citado artículo 368. Al contrario, sería en el texto del precepto legal, en su bien jurídico protegido y en su ubicación sistemática, donde habría de buscarse el concepto de droga, sin despreciar el posible valor orientador de las listas de los Convenios internacionales, pero sin que el actuar judicial deba vincularse estrictamente a ellas. Acaso estas posiciones pequen de pretender la consagración, en este ámbito, de un excesivo 
arbitrio judicial, dado que su acogimiento supondría dejar absolutamente en manos de los tribunales la determinación de qué concretas sustancias hayan de considerarse drogas ilícitas y cuales otras no, con la inevitable merma de la seguridad jurídica que exige el mencionado principio de legalidad. En todo caso, se trata de posiciones doctrinales minoritarias y rechazadas por la jurisprudencia.

\section{Artículo 368 del Código Penal}

Los que ejecuten actos de cultivo, elaboración o tráfico, o de otro modo promuevan, favorezcan o faciliten el consumo ilegal de drogas tóxicas, estupefacientes o sustancias psicotrópicas, o las posean con aquellos fines, serán castigados con las penas de prisión de tres a nueve años y multa del tanto al triplo del valor de la droga objeto del delito si se tratare de sustancias o productos que causen grave daño a la salud, y de prisión de uno a tres años y multa del tanto al duplo en los demás casos.

El artículo 368 del Código, considerado pues como ley penal en blanco, deberá ser completado con la legislación administrativa relativa a las drogas ilegales, fundamentalmente la Ley de 8 de abril de 1967 sobre estupefacientes, cuyo artículo 2.1 dispone que "a los efectos de la presente Ley se consideran estupefacientes las sustancias naturales y sintéticas incluidas en las Listas I y || de las anexas al Convenio Único de 1961 y las demás que adquieran tal consideración en el ámbito internacional por el procedimiento que reglamentariamente se establezca Ese Convenio Único sobre estupefacientes, de 30 de setiembre de 1961, ratificado por España el 3 de setiembre de 1966, es, por tanto, el primero de los tratados internacionales que complementan y concretan la ley española. Incorpora a su texto, como anexos, cuatro listas de sustancias. La lista I comprende, entre otros productos, el opio, la heroína, la morfina, la metadona, la cocaína y el cánnabis. La lista II incluye la codeína y el dextropropoxifeno. La lista III se refiere a preparados que no se prestan a uso indebido y, finalmente, la lista IV se dedica a las mezclas o preparados, sólidos o líquidos, que contengan las sustancias de las dos primeras listas.

A efectos penales se consideran pues estupefacientes las sustancias incluidas en las listas I, II y IV (mezclas de las dos primeras) del Convenio Único, así como también las que luego han ido añadiéndose, en el ámbito nacional español, por el procedimiento reglamentario que se establece, que se ha ido ejecutando posteriormente y hasta el momento a través de diversas órdenes ministeriales.

El otro texto internacional importante relativo a estas materias es el Convenio de Viena sobre sustancias psicotrópicas de 21 de febrero de 1971, que cuenta con dos anexos, el primero con cuatro listas de sustancias psicotrópicas, referidas respectivamente a alucinógenos (LSD, THC, DMT, STP, DOM y otros), anfetaminas, barbitúricos y otras sustancias (tales como la anfepramona, el meprobamato y la metacualona). Por su parte el segundo anexo del Convenio comprende y relaciona sustancias que, no siendo propiamente psicotrópicas, se consideran asimilables a ellas: entre otras sustancias, las benzodiazepinas, el fenproporex y la etilanfetamina.

Al igual que ocurre con el Convenio sobre estupefacientes, también éste sobre psicotrópicos contiene un mecanismo de actualización periódica de las sustancias incluidas en sus listas anexas, que, en el derecho español, se ha reflejado en sucesivas Ordenes Ministeriales a través de las cuales se han incorporado sucesivamente a dichas lista nuevas sustancias.

En lo relativo a las sustancias objeto de nuestro análisis, la cocaína se encuentra incluida, como ya se dijo, en el Convenio internacional de 1961 sobre estupefacientes y se considera, por tanto, como droga ilícita en el derecho penal español, exigiendo dicho tratado que la sustancia contenga al menos un $0,2 \%$ de principio activo para ser calificada como tal estupefaciente. 
Por su parte las sustancias LSD, PCP (fenciclidina), XTC, anfetamina y metanfetamina se encuentran incluidas en el Convenio de Viena de 1971 sobre psicotrópicos.

La 3,4-metileno dioxianfetamina, o MDA, fue incorporada al listado de sustancias "ilegales" mediante Orden Ministerial de 12 de julio de 1985.

Las sustancias MDMA, DMA y PMA fueron añadidas al listado de drogas ilegales por la Orden Ministerial de 30 de mayo de 1986.

La MDEA se incorporó al referido catalogo de sustancias a través de la Orden Ministerial de 19 de octubre de 1990.

La sustancia 4-MTA (4-metiltioanfetamina) fue incluída en la lista de drogas psicotrópicas por la Orden Ministerial de 31 de enero de 2000.

A su vez, la Orden Ministerial de 19 de febrero de 2002 añadió a esa lista las sustancias GHB (gammahidroxibutirato) y 2C-B (4bromo-2,5-dimetoxifeniletilamina).

Finalmente, la PMMA (parametoximetilanfetamina) se adicionó a la relación de sustancias psicotrópicas mediante Orden Ministerial de 15 de julio de 2002.

Por otra parte, hasta el momento actual (enero de 2003), la ketamina, sustancia utilizada como anestésico en el ámbito veterinario y en los últimos tiempos desviada al consumo humano, no se encuentra catalogada como "droga ilegal" y, por tanto, su tráfico no constituye delito en España.

\section{CATEGORÍAS LEGALES: DROGAS “DURAS" $Y$ "BLANDAS"}

El Código Penal divide las drogas ilegales en dos categorías, atendiendo a la mayor o menor nocividad de sus efectos. El texto legal alude a "sustancias que causan grave daño a la salud", cuyo tráfico se sanciona más severamente, mientras que los delitos cometidos con otras drogas "blandas" no tan nocivas son castigados con penas inferiores. Sin embargo, el Código no determina qué sustancias concretas deban ser consideradas legalmente como especialmente dañinas. $\mathrm{Ha}$ tenido que ser la jurisprudencia la que clasificara de una u otra forma cada una de las drogas ilegales contenidas en los tratados internacionales ya mencionados.

La cocaína ha sido siempre calificada como droga que causa grave daño a la salud (STS de 25 de octubre de 1983, 8 de febrero de 1984, 29 de abril de 1985, 18 de noviembre de 1987 y 12 de julio de 1990, entre muchas otras), y ello con independencia de su forma de presentación o grado de pureza. Así, se ha considerado droga especialmente dañina tanto el crack (STS de 6 de febrero de 1991, 20 de enero de 1992, 20 de mayo de 1993, 16 de noviembre de 1994 y 20 de noviembre de 1997), como la mezcla de cocaína con heroína o speed ball (STS de 21 de mayo de 1993), e igualmente una sustancia conteniendo cocaína cuya pureza solo alcanzaba el $3,7 \%$ del producto (STS de 7 de noviembre de 2000).

EI LSD se ha considerado también drogas causante de grave daño a la salud (STS de 5 de octubre de 1983, 8 de febrero de 1984, 11 de mayo de 1984, 1 de junio de 1984, 15 de febrero de 1988, 31 de marzo de 1990 y 28 de setiembre de 1992).

Las anfetaminas se incluyen, así mismo, por la jurisprudencia entre las drogas "duras" (STS de 20 de abril de 1996, 19 de octubre de 1996, 16 de abril de 1997, 1 de julio de 1997 y 3 de febrero de 1998), al igual que la MDMA (STS de 11 de octubre de 1993, 24 de enero de 1994, 31 de enero de 1994, 1 de junio de 1994, 25 de junio de 1994, 15 de noviembre de 1994, 12 de diciembre de 1994, 10 de enero de 1995, 15 de febrero de 1995, 3 de marzo de 1995, 6 de marzo de 1995, 17 de abril de 1995, 18 de mayo de 1995, 27 de setiembre de 1995, 14 de febrero de 1996, 11 de setiembre de 1996 y 10 de julio de 2000), MDA (STS de 5 de febrero de 1996 y 25 de abril de 1996) y MDEA (STS de 27 de setiembre de 1994, 1 de abril de 1996 y 1 de julio de 2000). 
En la categoría de drogas menos dañinas se encuentran solamente el cánnabis y sus derivados (STS de 4 de setiembre de 1983, 20 de febrero de 1984, 3 de diciembre de 1984, 24 de julio de 1991, 15 de octubre de 1991, 24 de setiembre de 1993, 8 de noviembre de 1995 y 17 de octubre de 1996), la metacualona (STS de 28 de abril de 1994), el dextropropoxifeno (STS de 11 de febrero de 1991 y 29 de noviembre de 1993) y las benzodiazepinas (STS de 21 de diciembre de 1995, 5 de julio de 1997, 18 de mayo de 1998, 20 de julio de 1998 y 1 de febrero de 1999).

Sobre la sustancia GHB no existe aun ninguna sentencia del Tribunal Supremo, ni tampoco relativas a las drogas 4-MTA, 2C-B y PMMA.

Debe advertirse que la inclusión de la sustancia en una u otra categoría legal debe ser alegada y justificada en cada proceso penal por la parte acusadora. Por ello, si la acusación se formula únicamente por delito de tráfico de drogas blandas, no puede el tribunal sentenciador condenar por tráfico de sustancias gravemente dañosas, dado que se vulneraría el principio acusatorio (STS de 28 de junio de 1999).

\section{CONDUCTAS DELICTIVAS: ELTRAFICO DE DROGAS}

El artículo 368 considera autores del tipo penal a quienes "ejecuten actos de cultivo, elaboración o tráfico, o de otro modo promuevan, favorezcan o faciliten el consumo ilegal de drogas tóxicas, estupefacientes o sustancias psicotrópicas o las posean con aquellos fines".

Como puede observarse, la redacción del precepto configura con extraordinaria amplitud el ámbito de conductas típicas, constitutivas del delito de tráfico de drogas. La promoción, el favorecimiento o la facilitación, de cualquier modo, del consumo ilegal de drogas por otra persona, resulta, en principio, suficiente para subsumir la conducta del sujeto "activo" en el marco de esta figura delicti- va, considerada, desde el punto de vista técnico-jurídico, como una infracción criminal de peligro abstracto, tracto permanente y consumación anticipada.

Quedan pues incluidos dentro del tipo penal, inicialmente, todos los actos que supongan cultivo, fabricación, venta, transmisión o donación de alguna sustancia considerada como droga, así como el transporte y la mera tenencia de esa droga si se realizan con finalidad ulterior de trafico.

Las únicas actividades que no se penan respecto al uso de drogas son, precisamente, su compra, la tenencia por el tiempo necesario hasta el momento de consumirlas y el propio acto de consumo (STS 22 de junio de 1983, 11 de febrero de 1984, 2 de diciembre de 1984, 20 de febrero de 1985, 21 de mayo de 1985, 21 de noviembre de 1986, 18 de noviembre de 1987, 4 de octubre de 1988, 26 de junio de 1990, 8 de noviembre de 1991, 15 de octubre de 1992, 28 de enero de 1993 y 9 de diciembre de 1994, entre cientos más de ellas).

Al concepto de tráfico se refiere la STS de 16 de junio de 1987, afirmando que "tráfico equivale a transmisión de una cosa a otra $u$ otras personas, es decir, a traslación de la propiedad o posesión de las mismas, gratuita u onerosamente, total o parcialmente, directa o indirectamente, siempre y cuando, claro está, la transferencia implique promoción o favorecimiento del consumo de drogas tóxicas, estupefacientes o psicotrópicas".

El mero transporte de la droga, incluso sin interés económico por el transportista, constituye también acto típico penalmente, dado que contribuye a propiciar el consumo ilegal de la droga transportada por sus destinatarios finales. En tal sentido, la STS de 30 de setiembre de 1997 señala que "asumir el encargo de transportar una cantidad de droga hasta una discoteca es poner una condición necesaria para cerrar el círculo de distribución de tal mercancía, y en su acto de tráfico del que se responde como autor". En igual dirección se pronuncian las STS de 21 de enero de 1998 y 21 de febrero de 1998. 
Así pues, el texto legal configura con gran amplitud la conducta típica delictiva, hasta el punto de hacer que se difumine o, al menos, revista enorme dificultad, la distinción técnico-jurídica entre actos directos de ejecución delictiva (autoría en sentido propio), actos de colaboración imprescindible para el delito (coautoría por cooperación necesaria) y actos de ayuda meramente útil, pero no estrictamente necesaria, para la comisión del delito (complicidad).

Por ello, la jurisprudencia viene declarando que la figura de la complicidad en los delitos contra la salud pública es de difícil apreciación, dada la amplia tipicidad establecida en el artículo 368 del Código (STS de 3 de marzo de 1987, 19 de setiembre de 1987, 10 de octubre de 1995, 10 de octubre de 1997 y 4 de octubre de 2000), siendo tan sólo posible su aplicación en supuestos de mínima colaboración mediante conductas auxiliares en beneficio del verdadero traficante (STS de 15 de enero de 1991 y 24 de julio de 2002).

En concreto, se han calificado de complicidad hechos como el mero acompañamiento a los compradores para indicarles el domicilio de quien vendía la droga (STS de 9 de julio de 1987), la ocultación ocasional y de brevísima duración de una pequeña parte de la droga poseída por otro (STS de 30 de mayo de 1991, 30 de mayo de 1997 y 15 de octubre de 1998) o la ayuda prestada por quien no era dueño de la droga a otra persona poseedora de la misma para que intentase hacerla desaparecer ante la intervención policial inmediata (STS de 16 de junio de 1995). Fuera de esos excepcionales casos, cualquier intervención en el tráfico se considera autoría del delito.

Los delitos de tráfico de drogas no requieren, en ningún supuesto, el ánimo de lucro en su autor. Por ello, la donación de droga ha sido considerada siempre como delictiva por la jurisprudencia (STS de 6 de abril de 1989, 19 de mayo de 1989, 22 de octubre de 1990, 4 de febrero de 1991, 3 de mayo de 1991, 25 de enero de 1992, 14 de octubre de 1993, 26 de noviembre de 1994 y 6 de junio de 1997). Sin embargo, hay casos especiales de entre- ga de drogas que el Tribunal Supremo ha considerado no sancionables penalmente. En general, se trata de la transmisión de dosis mínimas y gratuitamente a una persona que ya es previamente adicta a la sustancia, por parte de un familiar o persona allegada a dicho consumidor y con la intención de evitarle los sufrimientos del síndrome de abstinencia o de ayudarle a intentar una paulatina desintoxicación mediante el consumo de dosis decrecientes (STS 2 de noviembre de 1992, 18 de diciembre de 1992, 29 de mayo de 1993, 15 de julio de 1993, 16 de setiembre de 1993, 6 de octubre de 1993, 16 de marzo de 1994, 8 de abril de 1994, 27 de mayo de 1994, 11 de junio de 1997, 14 de julio de 1997, 22 de enero de 1998, 22 de setiembre de 2000 y 29 de junio de 2002).

El consumo compartido de una droga entre usuarios habituales de la misma viene siendo también considerado no delictivo (STS de 12 julio de 1984, 6 de abril de 1989, 23 de marzo de 1991, 2 de noviembre de 1992, 25 de marzo de 1993, 27 de setiembre de 1993, 7 de febrero de 1994, 18 de setiembre de 1997, 3 de noviembre de 1997 y 27 de octubre de 1999).

El Tribunal Supremo reputa igualmente atípicos los actos de compra colectiva de droga destinada al consumo de los que la adquieren (STS 25 de mayo de 1981, 11 de noviembre de 1992 y 27 de enero de 1995), e incluso, la compra por encargo de un grupo, del cual forma parte el encargado adquirente de la droga y destinando ésta al consumo de ese propio grupo (STS 18 de diciembre de 1992, 4 de febrero de 1993, 18 de octubre de 1993 y 3 de junio de 1994). En tales casos, la jurisprudencia exige, para considerar el hecho como no punible, que los que se agrupen para la compra conjunta de la droga estén perfectamente identificados y formen un círculo reducido y cerrado de adictos a la sustancia, que proyecten consumirla en un lugar cerrado y de una sola vez, y que la cantidad adquirida sea escasa (STS de 24 de julio de 2002, 26 de julio de 2002 y 30 de setiembre de 2002). 
Un problema probatorio peculiar que en ocasiones se plantea es la valoración penal de la actuación de otras personas que conviven en el mismo domicilio con el autor directo de los actos de tráfico de drogas. La jurisprudencia es, en este punto, especialmente clara: la mera convivencia domiciliaria ni es, en si misma, un acto de cooperación con el traficante ni sirve de prueba de participación en los actos de tráfico.

Al respecto, la STS de 26 de julio de 1993 ya proclamaba que "el hecho de la unión matrimonial y el dato de viajar juntos no pueden ser, por sí solos determinantes de la inferencia de la participación de la esposa" en el tráfico ilícito llevado a cabo por el varón, sorprendido con la droga en el automóvil donde se hallaban ambos.

La STS de 30 de diciembre de 1993 afirma que "bajo la fuerza de los principios constitucionales, no puede admitirse ningún tipo de presunciones de participación. No es correcto ni ortodoxo en forma alguna atribuir al hombre el tráfico por el hecho de llevarlo a cabo la mujer o viceversa, por la circunstancia de la convivencia de ambos en el mismo piso o vivienda y el mayor o menor conocimiento que uno de ellos tenga del tráfico que realiza el otro. No se puede, por ello, atribuir la posesión de la droga para su venta o el tráfico de la misma indiscriminadamente a los dos. Hay que probar, fehacientemente y por medios plenos de aptitud incriminatoria o de cargo, que uno y otro llevaron a cabo actos que el legislador incorpora al núcleo de cada uno de los tipos en alguna de las modalidades de participación".

En el mismo sentido se ha pronunciado en bastantes más ocasiones la jurisprudencia. Incluso conociendo uno de los convivientes el tráfico desarrollado por otro en el domicilio, ello no le convierte en partícipe si no se demuestra una contribución concreta al hecho delictivo (STS de 13 de octubre de 1994, 14 de octubre de 1994, 20 de setiembre de 1995, 28 de noviembre de 1997, 6 de octubre de 1998, 12 de mayo de 1999, 4 de abril de 2000 y 29 de mayo de 2000).
Importa, por último, señalar que la naturaleza típica del delito de tráfico de drogas impide apreciar la figura del delito continuado, prevista con carácter general en el artículo 74.1 del Código Penal, cuyo tenor "el que, en ejecución de un plan preconcebido o aprovechando idéntica ocasión, realice una pluralidad de acciones $u$ omisiones que ofendan a uno o varios sujetos e infrinjan el mismo precepto penal o preceptos de igual o semejante naturaleza, será castigado, como autor de un delito o falta continuados, con la pena señalada para la infracción más grave, que se impondrá en su mitad superior".

La STS de 20 de febrero de 1993 puso de relieve el carácter de delito permanente de este tipo penal, contraponiéndolo a otros casos de delito continuado. Por su parte la STS de 18 de diciembre de 1993 consideró existente un delito único de tráfico de drogas, rechazando la aplicación de la continuidad delictiva, en un supuesto de venta a una pluralidad de compradores. También negaron la posible apreciación del delito continuado las STS de 18 de marzo de 1999 y 30 de setiembre de 1999, y la STS de 3 de julio de 2000 reiteró que "la singular estructura del delito contra la salud pública en la modalidad de tráfico de drogas, permite entender que una pluralidad de actos realizados por el mismo sujeto que favorece el tráfico o el consumo ilegal por otras personas constituye un solo delito aunque esté integrado por varias acciones".

En la misma línea, la STS de 23 de octubre de 2000 destaca que "la naturaleza del delito de tráfico de droga, de mera actividad, permanente y de peligro abstracto, hace difícil su consideración como delito continuado. En su amplia expresión tipificadora se integran tanto la posesión y tenencia para el tráfico, como los actos aislados de este tráfico y la reiteración de esta clase de actos, pues estos actos de disposición y entrega fragmentaria a otras personas de las drogas en razonable cercanía temporal se realizan ya sobre un delito consumado por la mera tenencia y detentación de esas sustancias 
con ánimo de entregarlas a cualquier otra persona con finalidad de ilícito tráfico".

Igualmente rechaza la aplicación del delito continuado la STS de 23 de abril de 2002.

\section{CONSUMO DE DROGAS Y TENENCIA PARA EL AUTOCONSUMO}

El consumo de droga no ha sido nunca objeto de sanción penal en España, ni lo es actualmente, y lo mismo puede afirmarse de la tenencia previa al consumo.

La redacción del artículo 344 CP dada por la Ley 44/1971 de 15 de noviembre, que estuvo vigente hasta la reforma operada por la Ley Orgánica 8/1983 de 25 de junio, incluía en la descripción de las acciones típicas delictivas la ejecución "ilegítimamente" de actos de tenencia de drogas. Sin embargo, tal expresión siempre fue interpretada por el Tribunal Supremo en el sentido de restringirla a la tenencia preordenada a la distribución posterior de la sustancia ilícita (STS de 6 de abril de 1973, 16 de octubre de 1973, 31 de octubre de 1973, 7 de diciembre de 1973, 21 de marzo de 1974, 20 de enero de 1975, 5 de mayo de 1975 y 24 de noviembre de 1975, entre otras).

A modo de resumen, señalaba la STS de 20 de marzo de 1980 que "como el consumo de drogas o estupefacientes es atípico, para que la mera tenencia se repute delictiva, es menester que quede acreditado que la poseída no se hallaba destinada al propio consumo". A partir de la reforma del Código de 1983, desapareció cualquier posible duda interpretativa, al eliminarse del texto del artículo la referencia a la "tenencia" de droga.

Especialmente clara es la STS de 11 de junio de 1993, la cual afirma que "Ios actos de autoconsumo de drogas tóxicas o estupefacientes no se hallan sancionados en el artículo 344 del Código Penal y, por tanto, son atípicos e impunes, sucediendo lo mismo con los actos de producción (cultivo, elaboración y fabricación) y con los preparatorios (tenencia y transporte), siempre y cuando, claro está, el destino de lo producido, poseído o transportado, sea el propio consumo del productor, tenedor o porteador".

La atipicidad penal del autoconsumo y de la tenencia de droga para ello, no obsta a que esas conductas resulten castigadas en el ámbito administrativo, con multas y otras posibles sanciones no privativas de libertad.

La Ley Orgánica 1/1992 de 21 de febrero, sobre Protección de la Seguridad Ciudadana, califica como infracciones administrativas, sin rango delictivo, las conductas que describe su artículo $25-1^{\circ}$, consistentes en "el consumo en lugares, vías, establecimientos o transportes públicos, así como la tenencia ilícita, aunque no estuviera destinada al tráfico, de drogas tóxicas, estupefacientes o sustancias psicotrópicas, siempre que no constituya infracción penal, así como el abandono en los sitios mencionados de útiles o instrumentos utilizados para su consumo". Esas conductas se reputan infracciones graves a la seguridad ciudadana y se sancionan administrativamente con multa de importe comprendido entre cincuenta mil una pesetas y cinco millones de pesetas, a lo que debe añadirse que sus autores "podrán ser sancionados, además, con la suspensión del permiso de conducir vehículos de motor hasta tres meses y con la retirada del permiso o licencia de armas, procediéndose desde luego a la incautación de las drogas tóxicas, estupefacientes o sustancias psicotrópicas", según establece el artículo 28 de la Ley.

\section{6.- CUESTIONES PROBATORIAS: ¿TRAFI- CO O AUTOCONSUMO?}

La tenencia de droga destinada únicamente al consumo propio no es sancionable penalmente. En cambio, la tenencia es delictiva cuando, al contrario, tiene por finalidad la distribución de la droga a otras personas. Así pues, determinar cual de esas dos intenciones animaba en cada caso al poseedor de la droga va a resultar crucial en múltiples proce- 
sos penales, en los que se encuentra probada la tenencia de la sustancia pero sin acreditación directa de ningún acto de tráfico de la misma.

Cabe evidentemente, la confesión por parte del sujeto de su intención de traficar con lo incautado, así como la posible declaración testifical de quienes habían concertado la compra de la droga a su poseedor (STS 19 de febrero de 1990). En estos casos se contará con prueba directa del ánimo tendencial de traficar con la sustancia. Ahora bien, cuando esas pruebas no existen, hay que acudir a la prueba indirecta o indiciaria. Ante el hecho, pues, de la posesión de droga y la alegación de su autor de dedicarla a su propio consumo, será preciso valorar judicialmente el conjunto de indicios disponibles para inferir el destino final de la sustancia, y para esa apreciación el Tribunal Supremo viene señalando como esenciales los siguientes hechos:

a) acreditación o no de la condición de consumidor del portador de la droga, y de cantidad habitualmente consumida por el mismo

b) cantidad de droga poseída

c) distribución de la droga en dosis ya preparadas para su posible distribución y presentadas en la forma habitual en el mercado ilegal

d) tenencia de productos utilizados habitualmente para adulterar la drogae) ocupación de instrumentos utilizados habitualmente para dividir la sustancia en dosis, tales como dinamómetros, balanzas de precisión, cuchillos con señales de haber sido calentados para cortar mejor hachís, pajitas de plástico para contener cocaína, pequeños recortes de plástico para confeccionar bolsitas termoselladas con heroína, speed o cocaína, etcétera

f) circunstancias del hallazgo policial de la sustancia, lugar de aprehensión y razones esgrimidas por el poseedor de la droga para encontrarse allí

g) incautación de cantidades notables de dinero sin procedencia lícita justificable h) existencia en poder del poseedor de la droga o en su domicilio de notas o contabilidades manuscritas indicativas de ventas de drogas

i) grabaciones, con autorización judicial, de conversaciones telefónicas de esa persona relativas a operaciones de compraventa de drogas

j) trasiego continuo de consumidores de drogas en el domicilio de la persona a la que se le ocupa la sustancia, con visitas muy breves, como indicio de posibles operaciones de venta al menudeo

k) actitud adoptada al producirse la ocupación policial de la droga, intentando deshacerse de ella, ocultarla o darse a la fuga

Del examen detenido de todo el material probatorio existente en cada caso ha de surgir, motivadamente, la convicción y decisión judicial sobre el destino o no al tráfico ilegal de la droga poseída.

No obstante, algunos de los posibles indicios mencionados poseen escasa fuerza persuasoria a la hora de alcanzar conclusiones racionales e indubitadas al respecto, abundando las críticas doctrinales en esta materia. Así, por ejemplo, el último de los hechos relacionados como posibles indicios, el comportamiento de quien intenta que no le sea hallada policialmente la droga que lleva consigo, no permite inferir una intención de tráfico ilegal. Como la propia jurisprudencia ha admitido "parece lógico ocultar la droga que se transporta, se destine al tráfico o al propio consumo, pues el que la posee bien sabe que, en cualquiera de los dos casos, se le descubren, se la han de intervenir" (STS de 12 de diciembre de 1992).

Lo que sí resulta claro es que la alegación por la persona en posesión de la misma sobre su destino exclusivo al consumo propio habrá de ir acompañada de la demostración de su condición de consumidor de esa sustancia (STS de 2 de febrero de 1994, 24 de mayo de 1996 y 3 de julio de 2002), mediante las oportunas pruebas documentales (historia clínica, enfermedades o padecimientos concomitantes o derivados de la drogodepen- 
dencia, atención recibida en unidades o centros especializados de deshabituación, etc.) y periciales (informe del médico forense $u$ otros especialistas). A ser posible, convendrá también la acreditación, al menos de forma aproximada, de la cantidad habitualmente consumida por el sujeto.

\section{CANTIDADES MÁXIMAS PARA EL AUTOCONSUMO}

Existencia del consumo y cantidad objeto del mismo son, como hemos visto, dos elementos que resulta fundamental acreditar para mostrar el destino de una sustancia al autoconsumo penalmente no sancionable, variando enormemente, en cada caso, la cantidad que cada persona pueda tener almacenada con esa finalidad. Se plantea entonces el posible límite cuantitativo, a partir del cual, como criterio general, pueda considerarse que la cantidad de la droga indica ya su destino al tráfico, por exceder de lo que un consumidor medio puede razonablemente tener en su poder en previsión de futuros consumos por su parte. La respuesta jurisprudencial no es excesivamente clara, como vamos a ver a continuación, examinando las principales resoluciones dictadas sobre esta materia.

Se afirma por el Tribunal Supremo que "hay ánimo de traficar si se trata de una cantidad que excede de la que razonablemente está destinada al propio consumo, y que está objetivamente preordenada al tráfico, por exceder de las previsiones de consumo de un drogadicto" (STS de 2 de enero de 1998), y una corriente jurisprudencial viene manteniendo que ha de atenderse a la cantidad que pueda consumirse en cinco días como máxima admisible para el autoconsumo atípico, aplicando para cada día la dosis media ordinaria, según la droga concreta de que se trate en cada caso (STS de 28 de enero de 1993, 5 de junio de 1997 y 16 de setiembre de 1997).

En aplicación de esa tesis, la STS de 28 de setiembre de 1990 confirmó la condena en un caso de aprehensión de 65 gramos de cocaína en el domicilio del acusado, afirmando que "excede de la cantidad destinada al consumo la que supera la que el procesado utiliza durante un maximun de tres a cinco días. Incluso partiendo de la declaración del procesado de que esnifaba de 4 a 5 gramos diarios - lo que el propio letrado recurrente pone en duda - la cantidad intervenida se extendería a dos semanas de consumo".

Refiriéndose a la cocaína, la jurisprudencia había considerado cantidades indicativas para el tráfico de cocaína, en supuesto de hecho diversos, las de 8 gramos (STS de 19 de setiembre de 1983), 26,2 gramos con una riqueza del 35\% (STS de 26 de enero de 1990) y 25 gramos con una pureza del 49,56\% (STS de 16 de julio de 1990).

La STS de 7 de noviembre de 1991 afirma que "la cantidad de cocaína ocupada, 14,97 gramos, excede a la que un consumidor medio suele utilizar. También este argumento encuentra apoyo matemático, pues si el procesado ha declarado que la papelina que llevaba era para esnifar cocaína, y visto que el contenido de aquélla era de 0,1 gramo, es claro que tal décima de gramo implicaba la existencia de 149,7 dosis de consumo, número que evidentemente es también significativo del propósito de venta; y que el hecho de llevar el procesado en el bolso de mano toda la cantidad de cocaína ocupada en el momento de su detención, tras un servicio de seguimiento por la policía, que sospechaba sus conexiones y que por ello fue seguido la noche de autos desde N., donde residía, hasta $\mathrm{C}$. , a cuya circunstancia de llevar encima aquella cantidad de droga, dio la inverosímil explicación de que se había olvidado de sacarla del bolso".

Por su parte, la STS de 9 de octubre de 1992 consideró que excedía de la normal previsión de acopio de un consumidor medio la cantidad en aquel caso incautada, que ascendía 13,34 gramos de cocaína.

Una cantidad superior a los 20 gramos de cocaína de notable pureza no fue por sí misma denotativa de su destino al tráfico, en la STS de 27 de octubre de 1983, que revocó la condena impuesta inicialmente al poseedor 
de la droga, afirmando esta resolución que "si al recurrente se le ocuparon 21,8 gramos de cocaína de una pureza del $75 \%$ y el consumo que hacía de tal sustancia era nada menos que el de 2 gramos diarios, no es posible, con tales datos, deducir de ellos que el acusado se dedicaba a la venta de tal producto cuando los propios jueces de instancia, conscientes de no poder describir ningún acto concreto que supusiera tráfico de drogas, principian la narración del suceso que se enjuicia con la penalmente inexpresiva frase de que la Policía Judicial de Zaragoza recibió una información confidencial en el sentido de que Alfonso Z.F. se dedicaba a comerciar con cocaína, y como dicha información no aparece en la sentencia constatada por prueba alguna - por lo que ningún valor en conciencia puede dársele - y el volumen de la sustancia aprehendida sólo permitía a su tenedor cubrir sus necesidades durante 10 días, lo que no es inusual, es claro que se infringió el citado artículo", dejando sin efecto, en consecuencia, la condena dictada.

Sin embargo, un año y medio más tarde, se confirmó la sentencia condenatoria dictada contra el poseedor de una cantidad similar. Afirma la STS de 29 de abril de 1995 que "los veinte gramos intervenidos con la pureza indicada del $24 \%$ representan casi cinco gramos absolutamente puros de cocaína. En este caso únicamente existe el dato objetivo que refiere tal cantidad, pues no se encontraron objetos complementarios que hubieran ayudado al juicio de valor. Se ha considerado como normal el depósito o la tenencia por parte del drogadicto de cantidades que supongan acopio para el propio consumo durante 5 días, aunque es muy difícil establecer a priori reglas fijas sobre la cuantía que el drogodependiente precise, que dependerá de la calidad del producto y de las necesidades que el hábito le imponga". Luego, tras diversas consideraciones complementarias y el repaso de la principal jurisprudencia hasta entonces existente, concluye esta sentencia que "aunque no se encontraran útiles complementarios para el tráfico, es evidente que los $20 \mathrm{~g}$. exceden de los permisibles para el propio consumo si el cocainómano necesitas no más de dos gramos diarios (sentencia de 28 de abril de 1993). La concurrencia de principios activos en la proporción indicada del $24 \%$ abunda en la tesis asumida por la instancia, pues tal grado de pureza es incluso excesiva para el consumo como no se la corte con los habituales productos adulteradores".

Resulta pues complicado establecer, a la vista de las resoluciones del Tribunal Supremo, un límite cuantitativo de cocaína en principio destinada al autoconsumo. Un buen compendio de la doctrina jurisprudencial, con numerosas citas de resoluciones anteriores, se contiene en la relevante STS de 26 de marzo de 1999, que confirma la absolución inicial decretada por la Audiencia Provincial de Guadalajara a favor de dos acusados, ambos consumidores habituales de fin de semana, que tenían en su poder conjuntamente 26 gramos de elevada pureza.

Advierte esta STS de 26 de marzo de 1999 que "la fijación de límites cuantitativos que sirvan para fundamentar el juicio de valor sobre la intención del acusado en orden a distinguir la tenencia para el consumo, la tenencia delictiva para traficar o la tenencia delictiva de notoria importancia, la fijación de tales límites, se repite, es una cuestión ciertamente irritante por los agravios comparativos que pueden originarse si se hace caso omiso de los supuestos de caso concreto (ver sentencias de 5 de octubre de 1993, 15 de octubre de 1992 y 12 de junio de 1991). Siendo ello no obstante necesario para orientar la justa inferencia de los jueces, se ha hablado, en cuanto a la cocaína, de unos $8 \mathrm{~g}$. como cantidades que en término medio podría estimarse propia para el consumo durante tres o cinco días. Siempre será reglas discutibles, solo orientativas. Eso dice la sentencia de 17 de enero de 1997. La abundante doctrina de esta Sala refuerza no solamente la peculiaridad de cada caso sino también el peligro de establecer unas reglas estáticas, rígidas e inamovibles ..... No se olvide que nos movemos, subjetivamente, en el área de lo volitivo, intelectual o anímico a la hora de juzgar sobre 
los hábitos personales o sobre la drogodependencia. De ahí, insistimos, el peligro de las conclusiones inamovibles. Piénsese sobre todo en que las posibilidades económicas del consumidor y las posibilidades de conservación de la droga sin detrimento de su calidad pueden dar lugar a juicios distintos que nunca serían por ello contradictorios".

Abordando el análisis concreto del caso en cuestión, insiste esta resolución en que "el problema es difícil. Ahora se trata de poco más de 26 g. de cocaína, con una pureza media del $70 \%$, poseída para el autoconsumo de los dos acusados absueltos, los cuales son consumidores habituales en los fines de semana, en la ciudad en la que pacífica y laboralmente conviven, ciudad tan alejada de la capital del Estado como para justificar el viaje realizado a ésta para hacer acopio del alucinógeno. De otro lado no existen indicios de clase alguna que de alguna manera señalen cualquier clase de actividad delictiva, en el mundo de la droga, por parte de los acusados. La resolución de la cuestión debatida estaría en el análisis del razonamiento llevado a cabo por los jueces de la Audiencia que vieron y oyeron lo que otros ojos y oídos no van a percibir después. Ese razonamiento, lógico, racional, completo y sensato, lleva a una conclusión absolutoria que, en base a lo expuesto y atendiendo al supuesto de caso concreto, lejos de la rigidez y de la inmovilidad, este Tribunal no considera justa su rectificación".

En conclusión, la jurisprudencia no ha señalado con claridad una cantidad de cocaína a partir de la cual se considere inferible, atendiendo al solo dato cuantitativo, el destino de la droga al tráfico ilegal, si bien, cierto número de sentencias sitúa ese límite teórico, de forma puramente orientativa y con todas las reservas y salvedades pertinentes, en torno a los 8 gramos de esta sustancia. Esta cantidad coincidiría, además, aproximadamente con la suma de cinco dosis de 1,5 gramos, que es la magnitud tenida en cuenta por el Tribunal Supremo como consumo medio diario de cocaína, a la hora de determinar la denominada cantidad de notoria importancia, como más abajo veremos.
Lo anterior no supone, obviamente, que la tenencia de cantidades inferiores de droga no se sancione como destinada al tráfico, si tal posesión va acompañada de otros elementos indiciarios que acrediten suficientemente ese destino. A modo de ejemplo, en este sentido, la STS de 15 de junio de 1995 mantuvo la condena de una persona, declarada como consumidora de cocaína y encontrada en posesión de una cantidad inferior a los cinco gramos, señalando, respecto a esa condición de cocainómano que "el dato no es en sí mismo decisivo porque es conocida en el ámbito de esta delincuencia la hipótesis de drogadictos en los que confluye la doble condición de consumidores y vendedores, siendo la venta la fórmula que les permite financiar el consumo; y en este caso - entrando en el aspecto sustantivo del tema - es razonable que el Tribunal sentenciador se haya inclinado a esta última tesis, dando al consumo un carácter accesorio, porque la posesión de la droga, aunque sea en la pequeña cantidad de 4,92 gramos, tiene significación indiciaria por el elevado grado de pureza $(74,25 \%)$ que permite el corte o adulteración en la venta al menudeo, en que no suele pasar del $15 \%$ el principio activo, con lo que la posibilidad de venta y difusión no puede descartarse; son, además, circunstancias que no se concilian con la simple calidad de consumidor la posesión de la droga fuera del domicilio y escondida cuidadosamente en el calzado, y no guarda coherencia con el nivel económico del sujeto en situación de paro sin que consten ingresos distintos en la fecha de autos, el disponer de un vehículo provisto de teléfono móvil, de 40.000 pesetas, que era el precio de la droga adquirida y de 36.500 en efectivo. Finalmente, el alto al automóvil por las fuerzas de seguridad no fue un hecho de puro azar, sino por sospechas de transporte que pasaron como tales al hecho probado. En consecuencia, y aun aceptando la cualidad de consumidor de cocaína del acusado, los elementos que facilita el factum son suficientes para deducir la dedicación al tráfico".

Como antes mencionamos, en el mes de octubre de 2001, el Tribunal Supremo empezó 
a definir el tope legal de la notoria importancia de cada droga, partiendo de lo que calcula es el consumo medio diario de un adicto a la sustancia y estimando como tal la cantidad de 1,5 gramos de cocaína, 180 miligramos de anfetamina, 60 miligramos de metanfetamina, 480 miligramos de MDMA, MDA o MDEA, y 600 microgramos de LSD.

Con anterioridad a ese momento, no se habían producido pronunciamientos jurisprudenciales claros sobre la cantidad de anfetamina que pudiera considerarse como presumiblemente destinada al consumo propio de su poseedor. El cálculo de un acopio de droga para cinco días de consumo medio, con arreglo al criterio señalado, arroja un resultado de 900 miligramos de anfetamina como posible cantidad indicativa de destino al autoconsumo no delictivo.

Por supuesto, y como sucede con cualquier otra sustancia, eso no supone que no pueda acreditarse el destino al tráfico de esas cantidades, o de otras mucho menores, por otros medios probatorios de demostración (por ejemplo, mediante la declaración testifical de la persona que se disponía a adquirir droga a su poseedor). Y, por otra parte, no supone tampoco que, en función de todos los indicios y circunstancias concurrentes en el caso, no se pueda considerar como destinada al autoconsumo de su poseedor una cantidad incluso superior de anfetamina, tal y como ha sucedido en algunas resoluciones. Por ejemplo, en un caso bastante especial, no se consideró probado el destino al tráfico de 47 pastillas y 6 trozos de anfetaminas, cuyo peso total era de 50,5 gramos, aunque sin constancia del grado de pureza de la sustancia (STS 19 de octubre de 1996).

En lo tocante a las sustancias MDMA, MDA o MDEA no existen tampoco límites claros en la jurisprudencia respecto a la cantidad máxima posiblemente dedicada al autoconsumo. Sin embargo, algunas resoluciones aportan afirmaciones de cierto valor indicativo al respecto.

El Tribunal Supremo ha considerado destinados al tráfico alijos compuestos por 162 cápsulas de MDMA (STS 8 de julio de 1.994),
140 comprimidos de MDMA (STS 3 de marzo de 1.995), 129 cápsulas de MDMA (STS 12 de diciembre de 1.994), 75 comprimidos de MDA (STS 5 de febrero de 1.996), 50 pastillas de MDEA (STS 21 de noviembre de 1.995), 45 pastillas de MDMA (STS 17 de abril de 1.995), 40 comprimidos de MDMA (STS 14 de febrero de 1.996), 32 pastillas de MDEA (STS 12 de julio de 1.996), 21 comprimidos de MDEA y 9,15 gramos de anfetamina (STS 1 de abril de 1.996) y 20 pastillas de MDEA (STS 22 de diciembre de 1.995).

La STS de 15 de noviembre de 1994 se ocupó de una incautación de cuatro comprimidos de anfetamina y diez de MDMA. La Audiencia Provincial había condenado y el recurso de casación interpuesto por la defensa de la persona acusada alegaba su intención de autoconsumo de la droga, penalmente atípico. El Tribunal Supremo confirma sentencia inicial condenatoria, y para ello se basa en un conjunto de indicios que permiten inferir la intención de tráfico: se trataba de un sujeto que decía consumir éxtasis en forma muy esporádica (ni diaria ni semanalmente, según su propia declaración), detenido a las cuatro de la madrugada en el interior de una discoteca cuando llevaba, dentro de un paquete de tabaco vacío, las catorce pastillas antes mencionadas, y que, además, había ofrecido unas confusas explicaciones autoexculpatorias que, en definitiva, no resultaron convincentes para la Audiencia provincial.

La STS de 23 de noviembre de 1994 se refiere a un caso de tenencia de 25,5 pastillas de éxtasis (MDMA) y dos papelinas, con peso total de 0,33 gramos, de una mezcla de cocaína y anfetamina. El recurrente había sido condenado por la Audiencia Provincial, que consideró destinadas esas sustancias al tráfico. La prueba de ese destino al tráfico la había inferido la Audiencia de dos datos fundamentales: por una parte, el acusado había manifestado en sus primeras declaraciones, debidamente asistido por abogado, que había comprado las drogas para vendérselas a sus amigos; por otra parte, cuando en el juicio oral se había retractado de esas declaraciones anteriores, indicando entonces que las 
había comprado para su consumo personal, no ofreció ninguna "explicación razonable del porte de dichas sustancias y todavía menos de que llevase encima veinticinco pastillas y media de éxtasis cuando, según su propia versión, tomaba diez o doce cada fin de semana". El criterio de la Audiencia es aceptado por el Tribunal Supremo, que confirma, en consecuencia, la sentencia condenatoria.

Las dos resoluciones anteriores sirven para destacar que en los casos en que se trataba de una cantidad moderada de droga, y hubo condena, el Tribunal se apoyó siempre en indicios distintos de la propia cantidad de sustancia para deducir su destino al tráfico: declaraciones de testigos o de otros implicados, confesión del acusado, declaraciones autoexculpatorias poco convincentes o contradictorias, ocultación de la droga, posesión de la misma en el interior de discotecas, observación policial de intercambios reiterados de dinero y objetos con terceras personas, etcétera. Sin embargo, en tres de las sentencias mencionadas sí afirma expresamente el Tribunal Supremo que la cantidad incautada, en si misma, excede de la que puede considerarse dedicada al autoconsumo.

En tal sentido, la sentencia de 22 de diciembre de 1995 confirma la condena impuesta a una persona que tenía en su poder 20 pastillas de MDEA, afirmando el Tribunal Supremo que "en cuanto al destino de la droga al tráfico el juicio de inferencia del tribunal se funda en datos objetivos (cantidad más de cinco veces superior al consumo diario, aún calculado muy generosamente, circunstancias de la ocupación, actividades precedentes del acusado, tenencia de una nota manuscrita con un relación de nombres con una cifra asignada a cada uno de ellos, que la Sala razonada y razonablemente identifica como relación de compradores) datos todos ellos que conducen a fundamentar y reforzar la corrección" de la sentencia recurrida que, por lo tanto, se termina confirmando.

La sentencia de 14 de febrero de 1996 resuelve un recurso interpuesto por el ministerio fiscal contra una sentencia absolutoria dictada por la Audiencia Provincial de Madrid, dictada en un caso en el que se habían ocupado policialmente 40 comprimidos de MDMA con un peso total de 8,2 gramos y una riqueza del $40 \%$ en principio activo. La intervención policial había tenido lugar cuando el acusado se encontraba, sobre las 5,30 horas de la madrugada de un sábado, en compañía de un grupo de jóvenes frente a un pub de una localidad cercana a la capital madrileña. El Tribunal Supremo considera que esa cantidad de droga "supera con creces la que se estima normal o adecuada para el consumo propio (cifrado en 50 a 150 mg. por toma)", afirmando que en este caso "la provisión de droga excede de la admitida por esta Sala como orientadora del destino al autoconsumo (3 a 5 días)". En consecuencia, revoca la sentencia inicial absolutoria y condena por tráfico de drogas gravemente dañosas para la salud.

La tercera resolución a que nos referimos (STS de 12 de julio de 1996) confirma la condena dictada por la Audiencia provincial, afirmando el Tribunal Supremo que "están plenamente acreditados como hechos base la tenencia de la droga por el acusado, el lugar donde éste se encontraba apostado (cerca de la puerta de un bar y próximo al punto donde tenía aparcado su vehículo), la realización de contactos con diversas personas a la puerta del bar, el hecho de que después de una breve conversación con ellas, el acusado se dirigía a su vehículo y buscaba algo debajo del asiento, retornando después el contacto; la reiteración de dicha maniobra en seis $u$ ocho ocasiones durante el tiempo en el que fue sometido a observación; la ocupación de la droga distribuida en pastillas, precisamente debajo de la alfombrilla del asiento del conductor, lugar donde el acusado se dirigía a buscar algo después del primer contacto con los supuestos compradores; así como la cantidad de droga ocupada, 32 pastillas de MDEA, superior a la necesaria para el consumo ordinario durante varios días".

Por otra parte, la aplicación del criterio ya expuesto (acopio de cinco dosis diarias de consumo medio) supondría situar la cantidad 
límite para autoconsumo de MDMA, MDA y MDEA en 2,4 gramos de la sustancia.

Respecto a las demás drogas de uso recreativo (LSD, GHB, etc) no existen resoluciones del Tribunal Supremo que traten directamente la cuestión ahora examinada.

\section{PENAS APLICABLES A LOS DELITOS DE TRAFICO DE DROGAS}

El delito de tráfico de drogas que causan grave daño a la salud, entre ellas cocaína, anfetamina, LSD, MDMA, MDA y MDEA, se castiga en el artículo 368 CP con pena de prisión de duración comprendida entre tres y nueve años y, además, con pena de multa, cuyo importe dependerá del valor de la droga objeto del delito: una vez calculado, se impondrá una multa de cuantía comprendida entre esa cifra y el triplo de la misma. El artículo $377 \mathrm{CP}$ establece que a estos efectos ese valor de la droga "será el precio final del producto o, en su caso, la recompensa o ganancia obtenida por el reo, o que hubiera podido obtener".

En la práctica judicial son tenidos en cuenta, como medio probatorio fundamental, los informes que elabora periódicamente la Oficina Central Nacional de Estupefacientes (OCNE), dependiente del Ministerio del Interior, relativos al precio medio de las drogas en el mercado ilícito.

En el segundo semestre de 2002, el precio estimado por la OCNE para la cocaína adquirida por kilogramos era de 33.455,42 euros, con una pureza media del $71 \%$. El precio de la misma sustancia comprada por gramos supone 59,03 euros/gramo, con una pureza media, en esta forma de presentación, del $50 \%$. Por último, el informe cuantifica la dosis de cocaína habitual en el mercado en algo menos de un quinto de gramo (179 miligramos), con una pureza del $42 \%$ y un precio de 13,30 euros/dosis.

Por su parte, la dosis de LSD tenía un precio en el mercado ilegal, según la referida estimación policial, de 8,54 euros y los fármacos anfetamínicos de 4,16 euros/unidad. El MDMA se valora por la misma fuente en 10,90 euros la dosis de 300 miligramos.

A las penas de prisión y multa que se impongan en cada caso, ha de añadirse otra pena cuando el delito haya sido cometido por empresario, intermediario en el sector financiero, facultativo, funcionario público, trabajador social, docente o educador, en el ejercicio de sus respectivos cargos o profesiones. En estos casos, el artículo 372 CP, ordena imponer, además de las penas correspondientes ordinariamente al delito, la de "inhabilitación especial para empleo o cargo público, profesión u oficio, industria o comercio, de tres a diez años". A los efectos de este precepto, se consideran facultativos a los médicos, psicólogos, personas en posesión de título sanitario, veterinarios, farmacéuticos y sus dependientes.

Como supuesto todavía más grave, se impondrá, junto con la pena de prisión y la de multa, la pena de inhabilitación absoluta de diez a veinte años cuando el delito fuere realizado por una autoridad, o un agente de la autoridad, en el ejercicio de su cargo.

La condena por delito de tráfico de drogas conllevará, a tenor de lo dispuesto en el artículo 374 CP, además de las penas señaladas, el comiso de las sustancias ilícitas, que serán posteriormente destruidas con arreglo al procedimiento reglamentariamente establecido. También serán objeto de decomiso los equipos y materiales utilizados para la elaboración de la droga $y$, en general, los vehículos, buques, aeronaves y otros posibles bienes y efectos de cualquier naturaleza que hayan servido de instrumento para la comisión del delito. Por último, serán igualmente decomisados todos los bienes provenientes del tráfico y las ganancias obtenidas con ellos, cualesquiera que sean las transformaciones que hayan podido experimentar.

Se exceptúan del comiso los bienes e instrumentos de lícita posesión que pertenezcan a un tercero de buena fe no responsable del delito, por ejemplo, el titular del vehículo que lo cede o alquila al autor del tráfico sin cono- 


\begin{tabular}{|c|c|c|c|}
\hline \multicolumn{4}{|c|}{ Penas aplicables en el delito de tráfico de drogas recreativas } \\
\hline PENAS & $\begin{array}{l}\text { TIPO BASICO } \\
\text { Art. } 368 \mathrm{CP}\end{array}$ & $\begin{array}{l}\text { TIPOS AGRAVADOS } \\
\text { Art. } 369 \mathrm{CP}\end{array}$ & $\begin{array}{l}\text { TIPOS ULTRAGRAVES } \\
\text { Art. } 370 \mathrm{CP}\end{array}$ \\
\hline PRISIÓN & $\begin{array}{l}\text { mínimo: } 3 \text { años } \\
\text { máximo: } 9 \text { años }\end{array}$ & $\begin{array}{l}\text { mín:: } 9 \text { años } \\
\text { máx.: } 13 \text { años } 6 \text { meses }\end{array}$ & $\begin{array}{l}\text { mín.: } 13 \text { años } 6 \text { meses } \\
\text { máx.: } 20 \text { años } 3 \text { meses }\end{array}$ \\
\hline MULTA & $\begin{array}{l}\text { tanto al triplo } \\
\text { valor droga }\end{array}$ & $\begin{array}{l}\text { tanto al cuádruplo } \\
\text { valor droga }\end{array}$ & $\begin{array}{l}\text { tanto al séxtuplo } \\
\text { valor droga }\end{array}$ \\
\hline $\begin{array}{l}\text { INHABILITACION } \\
\text { ESPECIAL }\end{array}$ & \multicolumn{3}{|c|}{$\begin{array}{l}\text { (para empleo o cargo público, profesión, industria o comercio) } \\
3 \text { a } 10 \text { años }\end{array}$} \\
\hline $\begin{array}{l}\text { INHABILITACION } \\
\text { ABSOLUTA }\end{array}$ & \multicolumn{3}{|c|}{$\begin{array}{l}\text { (si el hecho lo comete la autoridad en ejercicio de su cargo) } \\
10 \text { a } 20 \text { años }\end{array}$} \\
\hline
\end{tabular}

cer que va a ser utilizado para la comisión del mismo.

Dispone también el Código Penal la posibilidad de que los bienes, efectos e instrumentos objeto del comiso puedan ser aprehendidos y puestos en depósito desde el primer momento del proceso penal por la autoridad judicial, con el fin de garantizar la efectividad del comiso. Incluso puede acordar el juez que durante la tramitación del procedimiento esos bienes puedan ser utilizados provisionalmente por la policía, con las debidas garantías para su conservación. Una vez sea definitivo el comiso, alcanzada la firmeza de la sentencia condenatoria en que se haya acordado, los bienes quedan adjudicados al Estado.

\section{TIPOS AGRAVADOS DE TRAFICO DE DROGAS}

Además de la distinción que efectúa el artículo 368 CP entre drogas "duras" y "blandas", el artículo 369 CP establece otra importante diferencia entre conductas básicas de tráfico de drogas y actuaciones más graves. Al tipo básico de tráfico le corresponden las penas ya examinadas. En los supuestos de tráfico grave las penas a imponer serán la de prisión con duración de nueve años a trece años y seis meses, y además la de multa de cuantía entre el valor de la droga y el cuádruplo del mismo.
Existen en el Código Penal nueve supuestos distintos de tráfico agravado, recogidos en el citado artículo 369, coincidente en su contenido con el anterior artículo 344 bis a) del Código Penal de 1973.

De esos nueve tipos agravados el que mayor problema interpretativo suscita es el de su apartado $3^{\circ}$, relativo a los casos en que "fuere de notoria importancia la cantidad de drogas tóxicas, estupefacientes o sustancias psicotrópicas objeto de las conductas a que se refiere el artículo anterior". Nos detendremos en su análisis.

El texto legal no se pronuncia sobre la cantidad de droga a partir de la cual se pueda considerar de notoria importancia, dejando pues su concreción a la labor jurisprudencial, lo que ha motivado abundantes y duras críticas doctrinales contra la utilización de un concepto jurídico tan sumamente indeterminado. Se aduce que la creación de un tipo penal absolutamente abierto supone atribuir al juez la facultad libérrima de determinar los supuestos de hecho en los que va a imponerse una pena superior en grado, lo cual resulta muy difícilmente compatible con la necesidad de taxatividad de los tipos penales y con el propio principio de legalidad. No obstante, la constitucionalidad del uso de este tipo de conceptos relativos, precisados de concreción judicial, ha sido reiteradamente admitida por el Tribunal Supremo (STS de 16 de diciembre de 1986, 11 de noviembre de 1989, 12 de febrero de 1993, 17 de junio de 1993 y 25 de noviembre de 1996) y por el Tri- 


\section{Artículo 369 del Código Penal}

Se impondrán las penas privativas de libertad superiores en grado a las respectivamente señaladas en el artículo anterior y multa del tanto al cuádruplo cuando:

1. ${ }^{\circ}$ Las drogas tóxicas, estupefacientes o sustancias psicotrópicas se faciliten a menores de dieciocho años o disminuidos psíquicos, o se introduzcan o difundan en centros docentes, en centros, establecimientos y unidades militares, en establecimientos penitenciarios o en centros asistenciales.

2. ${ }^{\circ}$ Los hechos fueren realizados en establecimientos abiertos al públicos por los responsables o empleados de los mismos.

3. ${ }^{\circ}$ Fuere de notoria importancia la cantidad de drogas tóxicas, estupefacientes o sustancias psicotrópicas objeto de las conductas a que se refiere el artículo anterior.

4. Las citadas sustancias o productos se faciliten a personas sometidas a tratamiento de deshabituación o rehabilitación.

5. ${ }^{\circ}$ Las referidas sustancias o productos se adulteren, manipulen o mezclen entre sí o con otros, incrementando el posible daño a la salud.

6. El culpable perteneciere a una organización o asociación, incluso de carácter transitorio, que tuviere como finalidad difundir tales sustancias o productos aún de modo ocasional.

7. ${ }^{\circ}$ El culpable participare en otras actividades delictivas organizadas o cuya ejecución se vea facilitada por la comisión del delito.

8. ${ }^{\circ}$ El culpable fuere autoridad, facultativo, funcionario público, trabajador social, docente o educador y obrase con abuso de su profesión, oficio o cargo.

9. ${ }^{\circ}$ Se utilice a menores de dieciséis años para cometer estos delitos.

bunal Constitucional (sentencias 62/82 y 133/87).

En líneas generales, la jurisprudencia ha venido estableciendo como razón de la agravación el mayor peligro potencial que supone para la salud pública una cantidad elevada de droga, al poder alcanzar su difusión a un número considerable de personas (STS de 12 de febrero de 1993 y 28 de abril de 1995).

El límite concreto de la notoria importancia se venía estableciendo por el Tribunal Supremo, desde 1984, en la cantidad que supondrían 200 dosis medias de cada tipo de droga
(STS de 9 de octubre de 1987). Sin embargo, en los últimos meses de 2001 se produce un importante cambio jurisprudencial, iniciado con un Acuerdo del Pleno de la Sala de lo Penal del Tribunal Supremo de 19 de octubre de ese año, elevando dicha cantidad a la suficiente para proporcionar 500 dosis diarias de consumo medio, calculado este último a tenor de lo indicado en un informe anterior del Instituto Nacional de Toxicología, de 18 de octubre de 2001, recabado al efecto por el propio Tribunal Supremo.

Con el nuevo criterio, la cantidad de notoria importancia comienza a partir de 750 gramos de cocaína, 240 gramos de MDMA, MDA o MDEA, 90 gramos de anfetamina, 30 gramos de metanfetamina y 300 miligramos de LSD.

Al respecto, la STS de 6 de noviembre de 2001 anuncia que "es claro que la seguridad jurídica y el principio de igualdad en la aplicación de la ley imponen establecer unos criterios precisos, que puedan aplicarse generalizadamente a toda clase de drogas y que concreten aquello que es considerado como notoriamente importante a estos efectos".

Continua la misma resolución afirmando que "tratándose de tráfico de estupefacientes, parece razonable partir de las cifras que cuantifican el consumo diario estimado de un consumidor medio, y a partir de ahí fijar la notoria importancia en atención a la cantidad de droga que permita abastecer un mercado importante (cincuenta consumidores) durante un periodo relevante de tiempo (diez días). Se obtiene así la cifra de quinientas dosis de consumo diario, aplicable a todas las drogas, que ha merecido la aprobación del Pleno de esta Sala. Para garantizar la uniformidad en la aplicación del subtipo se toma como pauta de referencia para determinar el consumo de cada una de las drogas el informe de 18 de octubre de 2001 emitido a solicitud de esta Sala por el Instituto Nacional de Toxicología. En lo que se refiere a los supuestos más frecuentes, las quinientas dosis equivalen a 750 gramos para la cocaína, 300 para la heroína y 2.500 gramos para e hachís".

Por su parte, la STS de 18 de febrero de 2002 reconoce que "es claro que en esta 
determinación se efectúa una valoración ponderadamente discrecional. En la doctrina se ha cuestionado que por qué se parte de la cifra de cincuenta consumidores y o de la de cuarenta o sesenta. Como sucede con otras determinaciones similares, por ejemplo, la cuantía de lo que este Tribunal considera especial gravedad atendiendo al valor de la defraudación, en el delito de estafa, es claro que finalmente siempre deberá señalarse un parámetro concreto, que es el fruto de una valoración ponderada y que puede ser cuestionado, como podría serlo otro similar. Como sucedía con el parámetro anterior, de doscientas dosis, el actual, de quinientas, es discutible, pero es el que la mayoría de esta Sala ha estimado más adecuado a las finalidades perseguidas por la aplicación del subtipo. Cuando el legislador utiliza este tipo de conceptos, delega necesariamente en los Tribunales, y en última instancia en el Tribunal Supremo, su necesaria concreción".

Expresan los mismos criterios las STS de 12 de noviembre de 2001, 14 de noviembre de 2001, 12 de diciembre de 2001, 11 de abril de 2002, 17 de abril de 2002, 30 de abril de 2002, 8 de mayo de 2002, 27 de junio de 2002, 9 de setiembre de 2002 y 25 de setiembre de 2002.

En todo caso, la jurisprudencia resalta que lo que se tiene en cuenta para comprobar si se ha superado el tope de la notoria importancia no es el peso total de la sustancia incautada, sino la parte de ese peso correspondiente a droga pura, descontando la parte que corresponda a adulterantes o excipientes. De esa forma, de un alijo, por ejemplo, de 900 gramos de cocaína, con una pureza del $80 \%$, se computarán sólo los 720 gramos de sustancia pura, con lo que no se aplicará el tipo agravado.

La ausencia de esa nota de pureza de la sustancia impidió que se aplicase el tipo agravado por la notoria importancia en un supuesto de incautación policial de un alijo con "un peso de cuatro kilos y novecientos cuarenta y cuatro gramos, sin que conste el grado de pureza o concentración de la anfetamina" (STS 18 de octubre de 1995), precisamente por entender que al no constar ese porcentaje no podía darse por probado que cantidad efectiva de sustancia pura contenía el alijo, argumentando que el principio de legalidad "impide que el concepto jurídico indeterminado de notoria importancia pueda establecerse mediante hipótesis, por muy racionales que resulten".

Igualmente hay que advertir que la jurisprudencia viene descontando también, para comprobar la superación de la barrera de la notoria importancia, la parte de la droga poseída que se encuentre destinada al autoconsumo. Así pues, en los casos en que se considere probado, por una parte, la posesión de cierta cantidad de droga destinada al tráfico y, por otro lado, la adicción del sujeto a esa sustancia y el consiguiente destino de una parte de lo poseído al consumo del mismo, habrá que deducir esta última parte del total del alijo para determinar si el resto, objeto del tráfico ilícito, supera o no el límite de la notoria importancia (STS de 15 de octubre de 1991, 30 de abril de 1993, 9 de diciembre de 1994, 19 de setiembre de 1995 y 19 de julio de 2000).

\section{TIPOS ULTRAAGRAVADOS DE TRAFI- CO DE DROGAS}

Además de las conductas básicas de tráfico de drogas, y de los tipos agravados, el Código Penal contempla también una figura ultra agravada de delito, tipificada en su artículo y castigada con pena de prisión de duración mínima de trece años y seis meses, y máxima de veinte años y tres meses, y con multa con cuantía comprendida entre el valor de la droga y su séxtuplo.

Este tipo especialmente grave se aplica en dos supuestos: cuando las conductas de tráfico de drogas, además de encajar en algún tipo agravado del artículo $369 \mathrm{CP}$, revistan extrema gravedad, y cuando los reos hayan actuado como jefes de organizaciones delictivas dedicadas al tráfico. 


\section{Artículo 370 del Código Penal}

Los Jueces o Tribunales impondrán las penas privativas de libertad superiores en grado a las señaladas en el artículo anterior y multa del tanto al séxtuplo cuando las conductas en él definidas sean de extrema gravedad, o cuando se trate de los jefes, administradores o encargados de las organizaciones o asociaciones mencionadas en su número $6 .^{\circ}$ En este último caso, así como cuando ocurra el supuesto previsto en el número $2 .^{\circ}$ del mencionado artículo, la autoridad judicial podrá decretar, además, alguna de las medidas siguientes:

a) Disolución de la organización o asociación o clausura definitiva de sus locales o de los establecimientos abiertos al público.

b) Suspensión de las actividades de la organización o asociación, o clausura de los establecimientos abiertos al público por tiempo no superior a cinco años.

c) Prohibición a las mismas de realizar aquellas actividades, operaciones mercantiles o negocios, en cuyo ejercicio se haya facilitado o encubierto el delito, por tiempo no superior a cinco años.

El texto legal no ofrece ningún detalle sobre el concepto jurídico indeterminado "conductas de tráfico de extrema gravedad", en otra laguna más que ha debido cubrir la jurisprudencia. Obviamente, se vuelven a plantear en este extremo las mismas objeciones doctrinales, aun acrecentadas, que cuestionaban la constitucionalidad del concepto abierto de notoria importancia, las cuales, sin embargo, no han sido acogidas por la jurisprudencia penal y constitucional. Examinaremos ahora las resoluciones más relevantes al respecto.

La STS de 19 de junio de 1995 afirma que "nos hallamos ante un concepto - extrema gravedad - sumamente indeterminado, por lo que suscita dificultades en relación a las exigencias propias del principio de legalidad penal en su vertiente de lex certa, de tal modo que algún autor ha afirmado su inconstitucionalidad por no respetar dicho principio reconocido en el art. 25 de nuestra Ley Fundamental. Sin compartir tan radical postura (véanse las sentencias del TC 105/88, 69/89 y
150/91 entre otras), sí hemos de decir que las debidas garantías del ciudadano exigen una aplicación muy cuidadosa mediante una interpretación restrictiva de la mencionada expresión legal".

Tras establecer ese punto de partida, se ocupa esta resolución de advertir que la extrema gravedad no puede identificarse con una cantidad elevadísima de droga. Afirma la sentencia que "en tal línea de interpretación restrictiva, entendemos que no basta una exacerbación en la cantidad de droga para aplicar la agravante penal aquí examinada. El legislador ha previsto una agravación por la cantidad de primer grado, las del $n^{\circ} 3$ del art. 344 bis a (cantidad de notoria importancia) y sobre ésta podría haber establecido otra segunda referida a los casos extremos al respecto, pero no lo ha hecho así, pues no habla de extrema cantidad, sino de extrema gravedad".

¿Cuales son entonces los casos en que deba aplicarse este tipo hiperagravado?. La STS que estamos comentando señala que ha de atenderse, fundamentalmente, a cinco grupos de elementos que sistematiza así:

"1. Aunque no único, como ya hemos dicho, el criterio de la cantidad, ha de ser considerado imprescindible en estos casos. Si de cantidades pequeñas o normales se tratara, parece claro que nunca habría de aplicarse la agravación de segundo grado a que nos estamos refiriendo.

2. Otro criterio para la valoración de la extrema gravedad puede ser el de que concurran en el supuesto varias de las conductas relacionadas en el art. 344 bis a). Sin embargo, la del $n^{\circ} 6$ (pertenencia a una organización, aun transitoria) parece que poco puede añadir a la reprochabilidad del hecho, pues se pruebe o no su existencia, es lógico pensar que una organización siempre ha de existir para traficar con droga en las cantidades extremas a que nos estamos refiriendo.

3. Otro elemento que puede determinar un mayor reproche social contra estas conductas, puede ser el uso de elementos especialmente preparados para este tráfico ilícito, 
como ocurrió en el caso presente en que se utilizó un remolque frigorífico preparado para transporte de fruta en el que se había construido un departamento aislado donde se ocultaba la mercancía prohibida.

4. Ha de tenerse en cuenta, además, el papel que cada acusado desempeña en el hecho. Los jefes, administradores o encargados de la organización prevista como agravación específica en el $n^{\circ} 6$ del art. 344 bis a) en el mismo precepto que estamos examinando, pero en un inciso segundo separado por la conjunción disyuntiva "o" tienen asignada la misma pena con que se sancionan los casos de extrema gravedad. Por ello, no puede exigirse tal condición (de jefes, administradores o encargados) para aplicar la agravación del inciso $1^{\circ}$, pues si así lo hiciéramos dejaríamos a este inciso sin contenido (interpretación abrogatoria prohibida por el art. 117.1 de la Constitución Española). Ahora bien en el lado opuesto de la organización están los meros peones a quienes se encomiendan funciones subalternas, que carecen de toda capacidad de decisión. Entendemos que a estos meros subalternos no cabe aplicar nunca la agravación específica aquí estudiada. A tales personas de último rango la sociedad no les reprocha una "conducta de extrema gravedad" que parece habrá de aplicarse solamente a los jefes, administradores o encargados, por aplicación del inciso $2^{\circ}$, o a los escalones intermedios por aplicación del $1^{\circ}$.

5. Otro criterio que podría tenerse en cuenta es si se actúa en interés propio o al servicio de otra persona, para excluir de tal extrema agravación a estos últimos".

Respecto a la cocaína, la STS de 16 de febrero de 1999 aplicó el tipo hiperagravado en un supuesto de transporte de 1.754 kilogramos de dicha sustancia.

Por su parte, la STS de 20 de marzo de 1999, resumiendo la jurisprudencia anterior insiste en que "la propia indeterminación del concepto extrema gravedad exige una interpretación restrictiva y de minucioso examen en cada caso concreto", añadiendo que "en esa línea restrictiva la jurisprudencia señala como elementos que han de tomarse en con- sideración los siguientes: el criterio de la cantidad como ineludible aunque no único; la concurrencia simultanea de varias de las agravaciones que se recogen en el precepto; y el uso de grandes elementos de transporte especialmente preparados para el tráfico ilícito (fletaje de barcos, camiones de un cierto tonelaje, etc )".

En igual dirección, resalta la STS de 9 de octubre de 1999, que "el legislador, tanto en el Código de 1973 como en el vigente de 1995, ya ha previsto una agravación importante de la pena por la llamada agravación de primer grado, es decir, la notoria importancia, y la agravación de segundo grado solo puede referirse a casos extremos en que nos encontremos ante una cantidad de droga enormemente elevada, ciertamente extrema o absolutamente excepcional. Incluso esta hiperagravación no puede basarse únicamente en la cantidad objeto de tráfico, sino que requiere otros elementos cualitativos que acentúen al límite la gravedad de la conducta examinada en su globalidad, o lo que es lo mismo, hay que fijarse en el conjunto de elementos objetivos y subjetivos que conforman el concreto comportamiento enjuiciado".

Esta resolución termina confirmando la correcta aplicación del tipo hiperagravado por la extrema gravedad a un caso concreto que describe de la siguiente manera: "una operación de tráfico de drogas de cantidad extrema y excepcional que incluye $3.775 \mathrm{~kg}$ de hachís, como parte de una partida más voluminosa, descargada en las costas gallegas en tres sucesivas etapas, más otro desembarco de 600 kg de cocaína. Todo ello en operaciones realizadas con la intervención de numerosas personas, controladas por el acusado, intervención de embarcaciones varias, transporte en planeadoras, traslado a otras lanchas para el desembarco, empleo de vehículos terrestres, y encomienda y control de la distribución, todo ello en los términos precisos que los hechos probados reflejan. En definitiva se trata de una operación de gran escala que por la cantidad, número de personas intervinientes y uso de grandes elementos para su realización cumple las exigencias que la doctrina 
de esta Sala precisa para la apreciación de la extrema gravedad".

Por el contrario, la STS de 16 de diciembre de 1999 no consideró aplicable este tipo a un supuesto de transporte en un pesquero de algo más de $800 \mathrm{~kg}$ de cocaína por no apreciar la concurrencia de otros factores objetivos y subjetivos, añadidos al dato cuantitativo, que hicieran calificar esa conducta delictiva como extraordinariamente grave.

A su vez, la STS de 24 de octubre de 2000 mantiene la negativa a aplicar la agravación en cuestión si el único dato cuantitativo de la cantidad de droga no va unido a otros elementos, tales como la existencia de una organización criminal bien estructurada y la utilización de medios o métodos especialmente sofisticados o aptos para ejecutar impunemente el delito.

Afirma esta resolución que "esta agravación requiere unos requisitos de carácter objetivo, pero también subjetivos. Entre los primeros cuenta, no cabe duda, la cuantía de la droga aprehendida y su pureza, pero a ellos se deben añadir otros elementos sobre la forma de realizarse la acción, como son los instrumentos materiales para llevarla a efecto, la organización previa y, en conjunto, lo que podríamos denominar la logística especialmente preparada. En cuanto a lo subjetivo no cabe duda que debe tenerse en cuenta el papel o rol que hayan podido jugar los acusados en la operación en cada caso concreto, pues, insistimos, la norma nos habla de acción peligrosa y ese peligro no puede achacarse lo mismo a personas que juegan un papel importante y decisivo en la acción delictiva que a aquellos que son simples mandatarios o asalariados. Así a guisa de ejemplo, no se puede aplicar el mismo baremo de peligrosidad o medir por el mismo rasero al capitán del buque que transporta la droga que a un simple marinero aunque sea también componente de la tripulación".

En el caso concreto objeto de esta sentencia, lo aprehendido eran 118 kilos de cocaína, y el Tribunal Supremo afirma que "es cierto que nos encontramos ante una cantidad de droga muy elevada e importante, que podría determinar la aplicación de la agravación en conjunción con otras circunstancias, aun cuando tampoco puede calificarse de extrema o absolutamente excepcional". Sin embargo, continua afirmando la resolución "en el caso actual al margen de la cantidad de droga ocupada no se aprecia la concurrencia de otras circunstancias de agravación del art. 369 , pues la sala sentenciadora no estima acreditada la pertenencia a una organización, ni consta tampoco que el velero de recreo utilizado para el transporte dispusiese de compartimentos ocultos o estuviese especialmente acondicionado o preparado para ese tráfico ilícito. Por otra parte, desde la perspectiva subjetiva, no consta que los acusados representasen un papel principal en la formación o diseño de la operación sino que más bien se presentan como simples colaboradores últimos o recaderos del tráfico ilícito de que se trata, apareciendo en el primer plano y corriendo el máximo riesgo al participar en las fases más comprometidas de la operación, pero sin constancia de que sus conductas vayan más allá de esta intervención, directa e inmediata pero no necesariamente principal". En consecuencia, no se aplica el tipo hiperagravado por la extrema gravedad.

Por su parte, las STS de 14 de noviembre de 2001, 17 de abril de 2002 y 14 de mayo de 2002 mantienen la aplicación restrictiva de este tipo ultragrave a supuestos de excepcional despliegue organizativo para traficar con elevadísimas cantidades de droga, reiterando en lineas generales los pronunciamientos anteriores.

Analizada ya la jurisprudencia relativa a este concepto jurídico indeterminado, resulta obligado llamar la atención sobre la desproporción punitiva con otros delitos que se encuentran entre los más graves del Código Penal. Que una conducta de tráfico de drogas, por más grave que sea, pueda ser castigada con una pena máxima (veinte años y tres meses de prisión) superior incluso a la pena propia de un delito de asesinato (entre quince y veinte años) nos parece manifiestamente injusto. 


\section{1.- CONCLUSIONES}

El examen efectuado de la regulación en el derecho penal español y de la producción jurisprudencial sobre las drogas de uso recreativo nos conduce a las siguientes conclusiones:

a) El derecho español considera como drogas ilegales la casi totalidad de productos utilizados como sustancias de uso recreativo, incluyendo la cocaína en todas sus formas de preparación (clorhidrato de cocaína, crack u otras), la fenciclidina (PCP), LSD, anfetamina, metanfetamina, MDMA, MDA, MDEA, GHB, 2C-B y otras sustancias similares.

b) En la actualidad (enero de 2003) no se encuentra catalogada como droga ilícita en el derecho español la ketamina, por lo que el tráfico de esta sustancia no constituye delito.

c) El consumo de sustancias calificadas como drogas ilícitas es ilegal en España, por lo que puede ser sancionado administrativamente con multas. Sin embargo, no constituye delito. Tampoco es delito la tenencia de dichas sustancias destinada al autoconsumo de su poseedor y sin ánimo de transmisión a otras personas. Sin embargo, la intención delictiva de tráfico de la sustancia se presume cuando lo poseído supera claramente el acopio previsible para un consumo de pocos días. En muchas ocasiones se plantean dificultades probatorias a la hora de dilucidar el destino o no al tráfico ilegal de la droga incautada a personas que afirman ser consumidoras de ella.

d) Se considera legalmente tráfico de drogas cualquier acción de difusión, distribución o entrega de la sustancia a otras personas, o de favorecimiento del consumo ilegal por ellas. El tráfico de drogas se califica como delito y se castiga con penas de prisión y multas, cuya severidad depende, en parte, de la nocividad de la sustancia y, en parte, de la gravedad de la conducta delictiva. El Código Penal distingue entre drogas "duras" gravemente dañosas para la salud y drogas "blandas" que no causan ese grave daño. Por otro lado, el Código diferencia las conductas básicas de tráfico de drogas de otras actuaciones más graves.

e) Las drogas de uso recreativo más importantes del mercado ilegal en España se encuadran en la categoría penal de sustancias que causan grave daño a la salud, y su tráfico se sanciona con penas de prisión de duración comprendida, en principio, entre tres y nueve años, además de multa y otras posibles penas accesorias de menor entidad.

f) Los delitos de tráfico de drogas se sancionan más gravemente cuando la cantidad de droga objeto del tráfico excede de ciertos límites establecidos por la jurisprudencia del Tribunal Supremo, diferentes para cada sustancia. Esos topes están situados actualmente en 750 gramos de cocaína, 240 gramos de MDMA, MDA o MDEA, 90 gramos de anfetamina, 30 gramos de metanfetamina y 300 miligramos de LSD. A partir de esas cantidades, la pena correspondiente oscila entre nueve años y trece años y seis meses de prisión.

g) En casos excepcionales de tráfico de cantidades muy elevadas de drogas gravemente dañosas, desarrollado a gran escala por parte de bandas organizadas, la pena máxima aplicable a los jefes de dichas organizaciones puede llegar a veinte años y tres meses de prisión. 
